\title{
PENGEMBANGAN LEMBAR KERJA SISWA (LKS) DENGAN MODEL DISCOVERY LEARNING PADA MATERI SIFAT KOLIGATIF LARUTAN
}

\author{
Made Intan Pradnyamita, I Nyoman Tika, I Ketut Sudiana \\ Universitas Pendidikan Ganesha \\ e-mail: pradnyamitaintan12@gmail.com nyoman.tika@undiksha.ac.id \\ sudi.ana@undiksha.ac.id
}

\begin{abstract}
ABSTRAK
Penelitian ini bertujuan untuk: (1) menghasilkan dan mendeskripsikan karakteristik, (2) validitas, (3) tingkat keterbacaan Lembar Kerja Siswa (LKS) dengan model discovery learning pada materi sifat koligatif larutan. Jenis penelitian ini merupakan penelitian dan pengembangan dengan menggunakan model pengembangan dari 4-D Thiagarajan. Tahapan penelitian yang dilakukan adalah define, design dan develop. LKS yang dikembangkan terdiri empat subtopik bahasan. Validasi LKS melibatkan satu orang ahli isi, satu orang ahli desain dan media pembelajaran, satu orang ahli Bahasa, dan satu orang praktisi. Uji Keterbacaan dilaksanakan dalam dua tahap yaitu uji one to one yang melibatkan 3 siswa dan uji small group yang melibatkan 12 siswa kelas XII SMA Negri 5 Denpasar. Karakteristik LKS dengan model discovery learning pada materi sifat koligatif larutan, yaitu pembelajran berpusat pada siswa, siswa dituntut untuk menemukan sendiri pengetahuannya dengan cara mengeksplorasi dan memecahkan masalah kemudian menggabungkan pengetahuan baru yang telah dimiliki dengan pengetahuan yang sudah ada melalui sintak dari discovery learning. Hasil validasi LKS menunujukkan bahwa LKS yang dikembangkan memenuhi katagori baik. Berdasarkan hasil uji keterbacaan diperoleh tingkat keterbacaan yang baik dan mudah dipahami oleh siswa.
\end{abstract}

Kata kunci: lembar kerja siswa, discovery learning, sifat koligatif larutan

\begin{abstract}
This study aimed to (1) produce and describe the characteristics, (2) the validity, (3) the readability of Student Worksheets (LKS) with discovery learning models in the coligative properties of solutions. This type of research is research and development used the development model of 4-D Thiagarajan. The stages of the research conducted are define, design and develop. The developed worksheet consists of four subtopics. LKS validation involves one content expert, one design expert and learning media, one language expert, and one practitioner. Readability test were carried out in two stages, one to one involving 3 students and a small group involving 12 students of grade XII SMA Negri 5 Denpasar. Characteristics of LKS with discovery learning models in the material of colligative nature of solution, namely student-centered learning, students are required to find their own knowledge by exploring and solving problems and then combining new knowledge they have with existing knowledge through the syntax of discovery learning. The results of the LKS validation show that the LKS developed meets the good
\end{abstract}


categories. Based on the results of a readability test, also had good readability level and can be comprehended by students.

Keywords: student worksheet, discovery learning, colligative proporties of solution.

\section{PENDAHULUAN}

Ilmu kimia merupakan salah satu cabang IImu Pengetahuan Alam (IPA) yang mempelajari mengenai materi yang ditinjau dari segi struktur, sifat-sifat, perubahan, dan perubahan energi yang menyertai perubahan tersebut (Jespersen dalam Subagia, 2014). Berdasarkan Permendikbud (2014) kimia merupakan ilmu yang mempelajari mengenai segala sesuatu zat yang mana meliputi komposisi, struktur sifat, perubahan, dinamika dan energetika zat yang melibatkan keterampilan dan penalaran. Oleh karena itu pembelajaran kimia harus memperhatikan karakteristik ilmu kimia sebagai sikap proses, dan produk (Nurisalfah, 2015).

Salah satu materi yang terdapat pada mata pelajaran kimia adalah sifat koigatif larutan. Sifat koligatif larutan merupakan sifat larutan yang tidak bergantung pada jenis zat terlarut tetapi hanya bergantung pada konsentrasi partikel zat terlarutnya. Materi sifat koligatif larutan dianggap sulit oleh siswa, ini didasarkan hasil wawancara yang dilakukan kepada salah satu guru di SMA Negri 5 Denpasar. Berdasarkan hasil wawancara materi sifat koligatif larutan ini dianggap sulit oleh siswa dilihat dari $67 \%$ masih banyak siswa yang berada di bawah kriteria ketuntasan minimal (KKM) yaitu 75 . $\mathrm{Hal}$ ini sejalan dengan penelitian yang dilakukan oleh Hubbi (2017) pada materi sifat koligatif larutan $53 \%$ siswa belum mampu mencapai nilai KKM yaitu 75 .

Penyebab siswa tidak mencapai nilai KKM disebabkan oleh beberapa faktor yaitu guru, bahan ajar, media pembelajaran, materi, dan lingkungan belajar (Anisa, 2012). Media pembelajaran merupakan segala sesuatu yang dapat menyalurkan pesan, merangsang pikiran, perasaan dan kemauan dalam komunikasi antara pendidik dengan peserta didik sehingga dapat mendorong terjadinya proses belajar dan pembelajaran (Nurdin, 2016). Sehingga media pembelajaran yang baik dapat meningkatkan hasil belajar siswa. Terdapat berbagai macam jenis media pembelajaran salah satunya adalah lembar kerja siswa (LKS). Berdasarkan hasil wawancara LKS merupakan salah satu media pembelajaran yang paling sering digunakan dalam proses pembelajaran.

Lembar kerja siswa (LKS) merupakan salah satu media pembelajaran yang mana berupa lembaran kertas yang berisi materi, dan petunjuk-petunjuk pelaksanaan tugas pembelajaran yang harus dikerjakan oleh peserta didik, yang mengacu pada kompetensi dasar yang harus dicapai. Karakteristik LKS yang baik yaitu pertama kesesuaian desain dengan tujuan pembelajaran yang berangkat dari kompetensi dasar, kedua kesesuaian materi dan tujuan pembelajaran, ketiga kesesuaian elemen atau unsur dengan tujuan pembelajaran, keempat kejelasan penyampaian (Prastowo, 2015). Berdasarkan wawancara yang dilakukan pada salah satu guru kimia di SMAK Harapan Denpasar LKS yang digunakan pada proses pembelajaran kurang baik, hal ini dilihat pada LKS tersebut hanya memuat ringkasan materi dan pertanyaan yang mana pada LKS yang digunakan tidak memberikan kesempatan kepada siswa untuk menemukan sendiri pengetahuan yang dimiliki yang mana pada proses pembelajaran kurikulum 2013 siswa dituntut untuk menemukan pengetahuannya sendiri. Selain itu penelitian yang dilakukan oleh Tampubolon (2016) menyatakan LKS yang beredar masih memiliki kekurangan yaitu, tulisan yang digunakan masih kaku, kertas yang digunakan buram sehingga menyebabkan siswa kurang tertarik mengerjakannya.

Saat ini proses pembelajaran di sekolah menggunakan kurikulum 2013, yang mana dalam pengaplikasian kurikulum 2013 ini menggunakan pendekatan saintifik. Dalam pelaksanaan pendekatan saintifik diperlukan model pembelajaran yang sejalan yang mana telah direkomendasikan pada kurikulum 2013 itu sendiri seperti discovery learning. Discovery learning merupakan suatu model pembelajaran yang mampu mendorong siswa untuk bisa menyimpulkan suatu konsep berdasarkan aktivitas dan observasi yang dilakukan oleh siswa (Balim, 2009). Discovery learning memiliki tahaptahapan, yaitu stimulasi, identifikasi masalah, pengumpulan data, verifikasi, dan menyimpulkan. Langkah-langkah tersebut dapat dituangkan dalam LKS. Lembar kerja Siswa (LKS) dengan model 
discovery learning dipilih dikarenakan LKS dengan model discovery learning sesuai dengan karakteristik materi sifat koligatif larutan dan karakteristik siswa kelas XII.

Karakteristik materi sifat koligatif larutan dapat dilihat dari salah satu kompetensi dasar (KD) dari siaft koligatif larutan yaitu KD 3.1 yaitu menganalisis fenomena sifat koligatif larutan (penurunan tekanan uap jenuh, kenaikan titik didih, penurunan titik beku, dan tekanan osmosis), merupakan salah satu KD yang harus dicapai oleh siswa. Untuk mencapai KD tersebut siswa dituntut untuk mengamati suatu wacana berupa fenomena sifat koligatif larutan. Kegiatan mengamati ini dapat menimbulkan rasa ingin tau siswa terhadap materi sifat koligatif larutan. Materi sifat koligatif larutan masih dianggap sulit oleh siswa dikarenakan pada materi ini siswa sulit untuk mengaitkan konsep yang telah dimiliki oleh siswa dengan konsep yang akan dibangun. Menurut Mairisiska (2014) pembelajaran yang terjadi saat ini cenderung kearah menghafalkan definisi dan menyelesaikan rumus praktis tanpa menggali pemahaman konsep, kurangnya keaktifan siswa menyebabkan mereka sulit memahami materi. Berdasarkan hal tersebut dibutuhkan media pembelajaran yang mampu membantu siswa dalam menemukan konsepnya, sehingga LKS dengan model discovery learning tepat digunakan untuk materi sifat koligatif larutan.

Lembar kerja siswa (LKS) dengan discovery learning sesuai dengan karakteristik siswa kelas XII yang mana pada tahap ini siswa memasuki masa remaja (adolescence) dan pada masa ini siswa memiliki rasa ingin tahu yang tinggi sehingga pembelajaran dapat dimulai dengan pemberian stimulus yang akan merangsang rasa ingin tahu siswa untuk belajar. Hal ini sesuai dengan sintak model discovery learning. Selain itu siswa yang berada pada jenjang SMA sudah mampu dalam membuat hipotesis dari suatu permasalahan, serta mampu memecahkan permasalahan yang rumit. Oleh karena itu, lembar kegitan siswa dengan model discovery learning tepat digunakan dalam proses pembelajaran pada topik sifat koligatif larutan.

Berdasarkan uraian diatas, penelitian ini bertujuan (1) menghasilkan dan mendeskripsikan karakteristik, (2) mendeskripsikan validitas, (3) mendeskripsikan keterbacaan Lembar Kerja Siswa (LKS) dengan model discovery learning pada materi sifat koligatif larutan.

\section{METODE}

Penelitian ini merupakan penelitian pengembangan berdasarkan 4D Thiagarajan. Tahap pengembangan yaitu (1) define, (2) design, (3) develop. Karena adanya keterbatasaan waktu dan biaya menyebabkan penelitian ini dilakukan hanya sampai pada tahap develop yaitu validasi dan uji keterbacaan.

Pada tahap define mula-mula dilakukan anlisis awal guna mengetahui permasalahan yang terjadi pada proses pembelajaran. Kemudian dilanjutkan dengan analisis kurikulum untuk mengidentifikasi kompetensi yang akan diajarkan. Analisis yang dilakukan adalah analisis kompetensi inti dan kompetensi dasar yang bertujuan untuk menentukan jumlah dan jenis media pembelajaran analisis yang dilakukan berdasarkan permendikbud No. 24 tahun 2016. Setelah dilaksanakan analisis kurikulum dilanjutkan dengan perumusan tujuan pembelajaran. Perumusan tujuan pembelajaran dilaksanakan untuk menentukan tujuan pembelajaran yang sesuai dengan materi yang dipelajari dan juga sebagai dasar dalam menentukan isi LKS.

Pada tahap kedua yakni tahap design, pada tahap ini terdiri dari tiga langkah yaitu pemilihan media pembelajaran berdasarkan tahap define yang telah dilaksanakan. Langkah berikutnya yaitu pemilihan desain LKS yang didasarkan karakteristik materi dan tuntutan kurikulum. Setelah dilaksanakan pemilihan desain LKS dilanjutkan dengan perancangan awal LKS.

Setelah dilaksanakan tahap design dilanjutkan dengan tahap develop. Tahap develop ini dilaksanakan dalam dua langakah yaitu validasi dan uji keterbacaan. LKS divalidasi oleh ahli isi, ahli desain dan media pembelajaran, ahli bahasa dan praktisi. Setelah dilaksanakan validasi dilanjutkan dengan uji keterbacaan. Uji keterbacaan yang dilaksanakan terdiri dari dua tahap yaitu one to one yang mana terdiri dari tiga orang siswa yang yang mewakili kelompok tinggi sedang dan rendah. Setelah dilaksanakan uji one to one dilanjutkan dengan ujia small group yang terdiri dari 12 orang siswa.

Teknik pengumpulan data yang digunakan dalam penelitian ini adalah teknik wawancara, studi pustaka dan angket keterbacaan. Instrument yang digunakan dalam penelitian ini adalah pedoman 
wawancara, angket keterbacaan, dan lembar validasi. Data yang diperoleh dalam penelitian ini dianalisis sesuai dengan jenis dan kegunaanya dalam penelitian, yaitu analisis awal, analis karakteristik LKS, analisis validitas LKS dan analisis keterbacaan LKS.

Validitas LKS dideskripsikan peraspek kualitas produk berdasarkan tanggapan dan penilaian dari ahli dan praktisi, validitas LKS yang dibuat ditentukan dengan langkah-langkah sebagai berikut: (1) skor yang diperoleh dari masing-masing validator dihitung rata-ratanya terlebih dahulu (2) validitas LKS ditentukan dengan mengonversikan rata-rata skor total menjadi nilai kualitatif dengan menggunakan kriteria pada Tabel 1.

Tabel 1.

Skala Penilaian Lembar Validasi

\begin{tabular}{cl}
\hline Interval skor & \multicolumn{1}{c}{ Kategori } \\
\hline $3,5 \leq \bar{X}<4,0$ & Sangat valid \\
$2,5 \leq \bar{X}<3,5$ & Valid \\
$1,5 \leq \bar{X}<2,5$ & Kurang valid \\
$1,0 \leq \bar{X}<1,5$ & Tidak valid \\
\hline & (Koyan, 2012)
\end{tabular}

Keterbacaan LKS yang dikembangkan didapatkan dari angket keterbacaan yang diberikan kepada siswa. Pada saat uji keterbacaan siswa diminta untuk membaca dan mengerjakan LKS yang dikembangkan. Keterbacaan LKS yang dikembangkan ditentukan berdasarkan angket keterbacaan dengan langkah-langkah sebagai berikut: (1) skor yang diperoleh dari masing-masing siswa dihitung rata-ratanya terlebih dahulu; (2) rata-rata skor yang diperoleh dari masing-masing siswa dijumlahkan, dan kemudian dirata-ratakan kembali sampai diperoleh skor total; (3) keterbacaan LKS ditentukan dengan mengonversikan berdasarkan kriteria seperti pada Tabel 2.

Tabel 2.

Skala Penilaian Keterbacaan LKS

\begin{tabular}{cl}
\hline Interval skor & \multicolumn{1}{c}{ Kategori } \\
\hline $3,5 \leq \bar{X}<4,0$ & Sangat baik \\
$2,5 \leq \bar{X}<3,5$ & Baik \\
$1,5 \leq \bar{X}<2,5$ & Kurang Baik \\
$1,0 \leq \bar{X}<1,5$ & Tidak Baik \\
\hline
\end{tabular}

(Koyan, 2012)

\section{HASIL DAN PEMBAHASAN}

Hasil dari penelitian pengembangan ini yaitu Lembar Kerja Siswa (LKS) dengan Model discovery learning pada materi sifat koligatif larutan. Adapun hasil dari pengembangan LKS yang dilakukan sebagai berikut (1) Berdasarkan hasil analisis awal yang dilakukan yaitu dengan mewawancarai guru didapatkan beberapa masalah yang terjadi dalama proses pembelajaran sifak koligatif larutan sebagai berikut. LKS kimia yang digunakan pada proses pembelajaran yaitu siswa membaca berupa ringkasan singkat yang terdapat di LKS kemudian siswa diarahkan untuk melakukan percobaan berkelompok dan mengerjakan latihan soal yang terdapat pada LKS, (2) LKS yang digunakan pada proses pembelajaran kurang membantu siswa dalam menemukan konsepnya sendiri (3) Pada proses pembelajaran guru masih menggunakan metode ceramah dalam proses pembelajaran, yang menyebabkan siswa hanya menerima materi yang diajarkan. (4) Pada materi sifat koligatif larutan hanya $67 \%$ siswa yang mampu mencapai nilai KKM ini menandakan bahwa materi sifat koligatif larutan yang diterangkan oleh guru kurang dipahami oleh siswa ini berdasarkan hasil wawancara yang dilakukan pada guru menyatakan bahwa siswa yang mendapatkan nilai dibawah KKM yang terdiri dari 27-30 orang siswa per kelas. Setelah dilaksanakan analisis awal dilanjukan dengan analisis konsep. 
Analisis konsep dilakukan untuk mengidentifikasi konsep-konsep utama yang akan diberikan yang menjadi cakupan materi yang akan menjadi objek kegiatan pengembangan dan kemampuankemampuan yang harus dicapai oleh siswa. Untuk mendapatkan konsep-konsep pokok dalam kurikulum perlu dilakukan analisis kompetensi inti dan kompetensi dasar yang tercantum dalam Permendikbud No. 24 Tahun 2016. Berdasarkan hasil analisis yang dilakukan didapatkan empat kompetensi dasar yang harus dicapai oleh siswa, setelah dilaksanakannya analisis dilanjutkan dengan membuat indikator sesuai dengan kompetensi yang ada. Setelah dilaksanakan analisis konsep dilanjutkan dengan spesifikasi tujuan pembelajaran. Spesifikasi tujuan pembelajaran bertujuan untuk menentukan tujuan pembelajaran yang sesuai dengan materi yang dipelajari dan merupakan sebagai dasar dalam menentukan isi dari LKS yang dikembangakan. Setelah tahap define dilaksanakan dilanjutkan dengan tahap design LKS.

Pada tahap design ini dilakukan yaitu perancangan LKS dengan model discovery learning pada materi sifat koligatif larutan. LKS yang dikembangkan pada penelitian ini terdiri dari empat unit LKS yaitu tekanan uap jenuh, kenaikan titik didih, penurunan titik beku, dan tekanan osmosis. Seluruh LKS yang dikembangkan dalam penelitian ini menggunakan sintak dari discovery learning. Setelah tahap design dilaksanakan dilanjutkan dengan tahap develop.

Pada tahap develop ini terdiri dari dua tahap yaitu tahap validasi dan tahap uji keterbacaan. Validasi dilakukan dengan melibatkan satu orang ahli isi, satu orang ahli desain dan media pembelajaran, satu orang ahli Bahasa dan satu orang praktisi (guru kimia kelas XII). Berdasarkan hasil validasi yang dilakukan LKS yang dikembangkan termasuk dalam kategori vali dengan skor 3,10 hasil validasi dapat dilihat pada Tabel 3 .

Tabel 3.

Hasil Validasi LKS

\begin{tabular}{rlrc}
\hline \multicolumn{1}{c}{$\mathbf{N}$} & \multicolumn{1}{c}{ Komponen Penilaian } & $\begin{array}{c}\text { Hasil } \\
\text { Penilaian }\end{array}$ & $\begin{array}{c}\text { Katag } \\
\text { ori }\end{array}$ \\
\hline 1 & Kelayakan isi & 3,00 & Valid \\
2 & Karakteristik model discovery learning & 3,00 & Valid \\
3 & Kebahasaan & 3,13 & Valid \\
4 & Komponen penyajian & 3,00 & Valid \\
5 & Kegrafisan & 3,38 & Valid \\
\hline \multicolumn{2}{r}{ Skor Total } & $\mathbf{3 , 1 0}$ & Valid \\
\hline
\end{tabular}

Setelah dilaksanakan validasi dilanjutkan dengan tahap uji keterbacaan. Uji keterbacaan dilaksanakan dua tahap yaitu uji one to one yang melibatkan tiga orang siswa yang mewakili klompok tinggi sedang dan rendah. Berdasarkan hasil uji one to one one didapatkan skor 3,40 yang menandakan bahwa LKS yang dikembangkan termasuk kategori baik. Setelah dilaksanakan uji one to one dilanjutkan dengan revisi produk berdasarkan saran dan masukan yang diberikan oleh siswa. Setelah dilaksanakan uji one to one dilanjutkan dengan uji small group. Pada uji small group ini dilaksanakan dengan meminta siswa sebanyak 12 orang untuk membaca dan mengerjakan LKS yang dikembangkan. Berdasarkan hasil uji small group didapatkan skor yaitu 3,53 yang menandakan LKS yang dikembangkan termasuk kategori sangat baik. Berdasarkan rata-rata hasil uji one to one dan small group didapatkan rata-rata yaitu 3,46 dengan kriteria baik yang menandakan LKS yang dikembangkan mudah dipahami oleh siswa.

Berdasarkan hasil pengembangan LKS yang dilakukan, LKS yang dikembangkan memiliki karakteristik yaitu LKS yang dikembangkan oleh peneliti menggunakan sintak discovery learning secara konsisten yakni stimulus, identifikasi masalah, mengumpulkan data, mengolah data verifikasi dan menyimpulkan. LKS dengan sintak discovery learning ini mampu membantu siswa aktif dalam proses pembelajaran dan mampu membantu siswa memahami konsep dengan cara menemukan konsepnya sendiri. Hal ini sejalan dengan pendapat Nugrahaeni (2017) model discovery learning menuntut peserta didik untuk lebih aktif dalam menemukan konsep \& materi. Selain menggunakan sintak discovery learning LKS ini memiliki karakteristik yaitu fenomena yang disajikan pada setiap LKS spesifik sehingga siswa mudah memahami LKS yang dikembangkan. LKS yang dikembangkan ini 
termasuk LKS yang baik digunakan oleh siswa yang didukung oleh hasil validasi dan uji keterbacaan yang telah dilaksanakan.

Berdasarkan hasil uji validasi oleh ahli isi, ahli desain dan media pembelajaran, ahli Bahasa dan Praktisi yang menilai masing-masing aspek, lembar Kerja Siswa dengan model discovery learning pada materi sifat koligatif larutan yang dikembangkan valid untuk digunakan sebagai media pembelajaran. Namun, beberapa butir penilaian masih mendapatkan penilaian kurang sehingga diperlukan perbaikan. Selaian itu, perbaikan juga dilakukan berdasarkan pada saran dan masukan dari validator. Setelah validasi dilaksanakan tahap selanjutnya yaitu revisi desain LKS yang dikembangakan. Revisi dilakukan untuk memperbaiki kekurangan dari produk yang dikembangkan sesuai dengan saran dan masukan dari validator, agar LKS yang dikembangkan layak digunakan dalam proses pembelajaran. Validitas yang baik dari LKS yang dikembangkan didukung oleh hasil uji keterbacaan.

LKS yang dikembangkan ini memili keteerbacaan yang baik hal ini berdasarkan hasil uji keterbacaan yang telah dilaksanakan. Keterbacaan yang baik pada LKS yang dikembangkan menunjukkan bahwa LKS yang dikembangkan mudah dipahami oleh siswa dalam menggali pengetahuan dan mengajarkan siswa untuk belajar mandiri. LKS yang mudah dipahami oleh siswa dapat membantu siswa dalam proses pembelajaran dan mampu meningkatkan hasil belajar siswa. Hal ini sejalan dengan Prastowo (2013) bahwa LKS yang digunakan oleh siswa bertujuan untuk melatih kemandirian siswa dalam menggali pengetahuan. Selain itu LKS yang dikembangkan menggunakan tulisan, ilustrasi warna yang dapat membangkitkan minat siswa untuk belajar. Hal ini di dukung oleh penelitian yang dilakukan oleh Putri (2015) LKS dapat menarik dan membangkitkan motivasi siswa dalam proses pembelajaran karena penyajian tulisan, ilustrasi warna yang sesuai dengan materi.

LKS yang dihasilkan pada pengembangan ini dapat menjawab temuan hasil analisis awal yang telah dilakukan. Dengan adanya LKS ini, dapat membantu siswa dalam memahami pembelajaran. Proses pembelajaran dengan LKS ini diharapkan lebih maksimal melaui proses pembelajaran penemuan secara ilmiah yang mengikuti sintak model discovery learning.

\section{SIMPULAN DAN SARAN}

Berdasarkan hasil penelitian dan pembahasan dapat disimpulkan sebagai berikut. Karakteristik LKS dengan model discovery learning pada materi sifat koligatif larutan, yaitu pembelajran berpusat pada siswa, siswa dituntut untuk menemukan sendiri pengetahuannya dengan cara mengeksplorasi dan memecahkan masalah kemudian menggabungkan pengetahuan baru yang telah dimiliki dengan pengetahuan yang sudah ada melalui sintak dari discovery learning. Hasil validasi LKS menunujukkan bahwa LKS yang dikembangkan memenuhi katagori baik. Berdasarkan hasil uji keterbacaan diperoleh tingkat keterbacaan yang baik dan mudah dipahami oleh siswa.

Berdasarkan hasil penelitian di atas disampaikan saran kepada guru dan peneliti lain sebagai berikut, (1) Guru dapat mengembangkan LKS sifat koligatif larutan dengan model discovery learning pada materi sifat koligatif larutan yang dikembangkan sebagai salah satu alternatif dalam proses pembelajaran kimia, (2) Peneliti lain dapat melanjutkan penelitian ini sampai uji kepraktisan keefektifan dan dessiminasi untuk menghasilkan LKS sifat koligatif larutan yang layak digunakan (3) Paparan dalam penelitian ini dapat dijadikan referensi untuk mengembangkan LKS pada materi kimia lainnya dan pada bidang studi lainnya.

\section{DAFTAR RUJIKAN}

Anisa, D. A. 2016. Pengembangan Lembar Kerja Siswa Pada Materi Teori Tumbukan Berbasis Discovery Learning. Skripsi (diterbitkan online). Bandar Lampung: Universitas Lampung.

Balım, A., G. 2009. The Effects of Discovery Learning on Students' Success and Inquiry Learning Skills. Egitim Arastirmalari-Eurasian Journal of Educational Research, 35, 1-20.

Hubbi, M, \& Dasna, I.W., Wonorahardjo, S. 2017. Pengaruh Strategi Pemblajaran Praktikum Sifat Koligatif Terhadap Hasil Belajar Siswa Kelas XII. Jurnal Kimia dan Pendidikan. 2(1).

Nurdin, S \& Adriantoni. 2016. Kurikulum dan Pembelajaran. Jakarta: Rajawali Press

Peraturan Menteri Pendidikan dan Kebudayaan Nomor 24 Tahun 2013. Kemdikbud RI: Jakarta.

Prastowo, A. 2015.Panduan Kreatif Membuat Bahan Ajar Inovatif. Jogjakaerta: DIVA Press 
Vol. 3, No. 2, 2019

Subagia, I. W. 2014. Paradigma Baru Pembelajaran Kimia SMA. Seminar Nasional FMIPA Undiksha (hal. 152-163). Singaraja: Universitas Pendidikan Ganesha.

Tampubolon, S. C., Rosilawati, I., Fadiawati, N., 2016. Pengembangan Lembar Kerja Siswa Sifat Koligatif Larutan Elektrolit Berbasis Ketrampilan Proses Sains. Jurnal Pendidikan dan Pembelajaran Kimia. 5(2). 